\title{
Studies on Operational Parameters of Different Spray Nozzles
}

\author{
Sunil Shirwal $^{1 *}$, M. Veerangouda ${ }^{1}$, Vijayakumar Palled ${ }^{1}$, Sushilendra $^{1}$, \\ Arunkumar Hosamani ${ }^{2}$ and D. Krishnamurthy ${ }^{3}$ \\ ${ }^{1}$ Department of Farm Machinery and Power Engineering, College of Agricultural \\ Engineering, UAS, Raichur - 584104, India \\ ${ }^{2}$ Department of Entomology, Main Agricultural Research Station, \\ UAS, Raichur - 584104, India \\ ${ }^{3}$ Department of Agronomy, Agricultural Research Station Hagri, UAS Raichur, India \\ *Corresponding author
}

\begin{tabular}{|l|}
\hline Ke y w o r d s \\
Cotton spraying, \\
Droplet size, RSM, \\
Spray nozzle, Spray \\
uniformity
\end{tabular}

\section{A B S T R A C T}

Spraying is one of the most effective and efficient techniques for applying spray liquid to protect crops. The nozzle is a major component in determining the amount of spray applied to an area, the uniformity of application, the coverage obtained on the target surface and the amount of potential drift. Hollow cone, solid cone and 3D action nozzles were selected for the study, which were widely used by the local farmers for cotton crop. The selected nozzles were evaluated in spray patternator for different operating parameters. The operational parameters selected for the study were operating pressure and height of nozzle. The parameters were optimized by using CCRD Response Surface Methodology. The maximum discharge of 1.86, 2.46 and $3.201 \mathrm{~min}^{-1}$ was obtained at hollow cone, solid cone and $3 \mathrm{D}$ action nozzles, respectively at operating pressure of $1000 \mathrm{kPa}$ and nozzle height of $0.4 \mathrm{~m}$. Minimum droplet size of $114 \mu \mathrm{m}$ was obtained for hollow cone nozzle at operating pressure of $1000 \mathrm{kPa}$ and nozzle height of $0.4 \mathrm{~m}$. The minimum spray uniformity of 1.46 , 1.79 and 1.39 was obtained for hollow cone, solid cone and 3D action nozzles, respectively at $912 \mathrm{kPa}$ operating pressure and $0.26 \mathrm{~m}$ height of spray. The maximum droplet density of 156,105 and 85 numbers per $\mathrm{cm}^{-2}$ were obtained at $1000 \mathrm{kPa}$ operating pressure and $0.4 \mathrm{~m}$ nozzle height for hollow cone, solid cone and $3 \mathrm{D}$ action nozzle, respectively. The $\mathrm{CV}$ of volumetric distribution across all three selected nozzles was varied from 6.10 to 18.60 per cent. A hollow cone nozzle was optimized to be operated at $626 \mathrm{kPa}$ operating pressure and $0.56 \mathrm{~m}$ nozzle height with coefficient of variation in volumetric distribution of 11.31 per cent with a desirability level of 0.778 . 


\section{Introduction}

Crop yield is reduced mainly due to attack of pests, diseases and weeds. In India, crops are affected by over 200 major pests, 100 plant diseases, hundreds of weeds and other pests like nematodes, harmful birds and rodents. Approximately, 18 per cent of Indian crop yield potential is being lost due to insects, diseases and weeds which in terms of quantity would mean 30 million tonnes of food grain. The value of total loss estimated at Rs 50,000 million, representing about $18 \%$ of the gross national agriculture production (Manncsa, 2009). Among the various methods of pest control, chemical application is widely used for controlling disease, insects and weeds in the crops. They are able to save a crop from pest attack only when applied on time. They need to be applied on plants and soil in the form of spray, dust or mist and granule. Dusters and sprayers are used to apply the agro chemicals. But duster is less efficient than the spraying due to low retention of chemicals. Spraying is one of the most effective and efficient techniques for applying spray liquid to protect crops. Over 75 per cent of all pesticide applications are made as liquid sprays (Robert and Hipkins, 2012).

Pesticide application is complex process, the magnitude and uniformity of spray deposition is mainly influenced by target canopy characteristics, type of spray equipment and mode of operations and properties spray chemicals. Uniform distribution and deposition chemical spray from top to bottom plant canopy and the on the under sides of the leaves is of at most importance of effective control of pests. The pesticide need to be applied to particular target area occupied by insect, pest, disease or weed. Contamination to the environment by chemicals drifting out of the areas being treated has let to criticism for the use of pesticide. The low application efficiency of the existing mechanism also tends to the farmers to apply frequently and more chemicals in the field there by contaminating both soil and environment.

The primary aim of crop protection equipment (sprayers) is the reduction in the population of developmental stage of pest which is directly responsible for damage within individual fields and is most efficient when the chemical is applied economically on a scale dictated by the area occupied by the pest and the urgency with which the pest population has to be controlled taking the environment into consideration (Mathews, 1992). The proper selection of a nozzle type and size is essential for proper pesticide application. The nozzle is a major component in determining the amount of spray applied to an area, the uniformity of application, the coverage obtained on the target surface and the amount of potential drift. Spray deposition on the plant canopy, soil surface or on flying insects takes place by gravitational sedimentation or inertial impact, or a combination of both processes (Rahman, 2010). The transport of the spray droplets to the target is affected strongly by weather conditions especially wind, low humidity and high temperatures, which generally reduce impaction efficiency and increase drift (Matthews, 1992). Drift can be minimized by selecting nozzles that produce the largest droplet size while providing adequate coverage at the intended application rate and pressure (Safari et al., 2004). The size of the spray particle is plays on important role because it affects both efficacy and sprays drift of the pesticide and can also influence the environmental impact of the spraying operations. Efficacy of spray particle is mainly influenced by the amount of chemical used per unit area, deposition of chemical and percentage of chemical received in a target area. Other important spray characteristics influencing the efficacy of spray particle is spray angle, spray shape and volume 
distribution pattern (Minov et al., 2014). It is important to study nozzle performance because of its ultimate effect on the efficiency of the pesticide application process. The most important factors that are influenced by nozzle performance are the risk of spray drift, the quantity and the distribution of the deposit on the target and the uptake or mode of action of the chemical at the target surface. In this context a study was conducted to study the effect of different operating parameters on selected nozzles. The nozzles selected were more commonly used for various pesticide applications in the region.

\section{Materials and Methods}

The proper selection and use of spray nozzles is the most important part of pesticide application. The nozzle determines the amount of spray that is generated over a given area, uniformity of spray produced, coverage obtained and the amount of drift that occurs. Hence, three types of nozzles were selected for the studies which were most commonly used by the local manufacturers and farmers. The nozzles selected for the study were hollow cone nozzle, solid cone nozzle and 3D action nozzle.

The experiments were conducted to evaluate the three type of in a spray patternator at Department of Farm Machinery and Power Engineering, CAE, Raichur. A patternator is a device which can be used for quantification of spray discharged from a sprayer and to visualize its pattern. On a spray patternator, lateral distribution of pesticide from spray nozzles can be evaluated where spray from a nozzle is collected in many evenly spaced channels which make up the surface of the patternator. The spray patternator collection system was built according to specification found in ASTM standard E641-01, standard methods for testing hydraulic spray nozzles used in agriculture.
Hollow cone nozzles produce a circular spray pattern, where all the liquid spray jet is concentrated on the outer edge. These nozzles are generally used to apply insecticides or fungicides to leaf crops where complete coverage of leaf surface is important. In solid cone nozzles, droplets are distributed into volume which is limited by cone, having a origin point at the nozzle tip. In these nozzles, the spray fluid emerges from an orifice gets a tangential velocity when it passes through a tangential passage of swirl chamber. However, the extra liquid enters the swirl chamber centrally from its base so that the air core is filled to form a solid cone of droplets.3D action nozzles are the special purpose nozzles used for used for insecticides and pesticides applications. These nozzles have three numbers of orifices on the nozzle head. 3D spray nozzles tighten the spray pattern to substantially decrease small droplets - resulting in 50 to $75 \%$ less drift potential than conventional flat fan nozzles.

The operating parameters selected as independent variables were operating pressure and height of spray. The independent variables were fixed at five levels and as per central composite design a total number of 13 experiments were carried out (Table 1). The nozzle under test was mounted at the centre of the metallic frame and its tip pointing towards the patternator trough. The nozzle was connected to a spray lance, which was connected to the pump of the patternator. The height of the nozzle can be adjusting by sliding the frame after loosening the screw. The operating pressure was adjusted for different levels by rotating pressure regulating valve provided at the HTP pump. The variation of pressure in the system could be observed on the digital pressure gauge of the patternator. Spray operation was carried out for a period of $1 \mathrm{~min}$ in spray patternator. After each experiment, the performance parameters i.e., discharge rate, droplet size, 
droplet density, uniformity coefficient and spray volumetric distribution were determined.

Discharge of spray nozzles was measured by volume-time method. The spray volume was collected in measuring cylinder of 2.5 litres capacity for one minute duration from all channels of patternator at all levels of operating pressures and nozzle type. Discharge from individual spray nozzle was collected separately at a time.

Spray contains a large number of very small spheres of liquid known as droplets. The Magnesium Oxide (MgO) method was used for determining the droplet size. It had a spread factor that did not vary with droplet size or formulation. The spread factor for this method was 0.86 for the droplets of size range of 20-200 $\mu \mathrm{m}$. The MgOcoated glass slides were exposed to the droplet spectrum created by the hydraulic nozzles at different operating conditions. The stained slides were taken to the trinocular microscope, connected to computer, forming a computerized droplet size analyser. The true diameter of droplets was calculated by multiplying stain diameter on $\mathrm{MgO}$ slide by a factor of 0.86 . The size of the droplets measured by this method was volume mean diameter (VMD). The number mean diameter (NMD) was calculated manually using excel worksheet (Mathews, 1992). The ratio of VMD to NMD is uniformity coefficient.

The droplet density is also important along with droplet size for the quality of the spray since droplet density directly affects the volume of spray applied depending on the droplet size. By using computerized droplet size analyzer, the number of droplet spots on one square centimetre area of $\mathrm{MgO}$ glass slide was measured. The number of droplets per unit area was termed as droplet density.
The coefficient of variation in the spray volumetric distribution was determined by equation (1).

$$
C V=\frac{\sigma}{X_{m}} \times 100
$$

$\begin{array}{ll}\text { Where, } & \mathrm{CV}=\quad \text { Coefficient of } \\ \text { variation, } \% & \\ \sigma \quad= & \text { Standard deviation among the }\end{array}$ levels of spray volume

$$
\text { collected }
$$

$\mathrm{X}_{\mathrm{m}}=\quad$ Mean among the levels of spray volume collected

\section{Results and Discussion}

The performance parameters viz. discharge rate, droplet size, spray uniformity, droplet density and coefficient of variation in volumetric distribution were determined and analysed at different levels of the operating parameters. The observations obtained from the study were statistically analysed using response surface methodology using CCRD. The quadratic polynomial model was fitted to each designed model with respect to coded independent variables for the different response parameters.

\section{Influence of operating pressure and nozzle height on discharge rate}

The maximum discharge of $1.86,2.46$ and $3.201 \mathrm{~min}^{-1}$ was obtained at hollow cone, solid cone and 3D action nozzles, respectively at operating pressure of $1000 \mathrm{kPa}$ and nozzle height of $0.4 \mathrm{~m}$. The minimum discharge rate of $0.64,1.54$ and $2.021 \mathrm{~min}^{-1}$ was observed for hollow cone, solid cone and 3D nozzles at operating pressure of $400 \mathrm{kPa}$ and $0.40 \mathrm{~m}$ nozzle height. It can be depicted from Fig. $1(\mathrm{a}, \mathrm{b}$ and $\mathrm{c})$, that as the operating pressure was increased, the discharge rate was also increased for all selected nozzles. This was observed because the operating pressure was directly proportional to the square root of the 
discharge rate (Kepner et al., 2005). As the operating pressure increased the velocity of flow was also increased, hence discharge rate was found to be increased with increased pressure (Shashi et al., 2005). The nozzle height does not have any effect on the discharge rate. These results confirmed the statements made byIqbal et al., (2005) and Kathirvel et al., (2002). Among the two operational parameters, only operating pressure $(\mathrm{P})$ has significant effect on the discharge rate at 1 per cent level of significance, whereas nozzle height $(\mathrm{H})$ nonsignificant. The mean values of the discharge rates were $1.42,2.03$ and $2.611 \mathrm{~min}^{-1}$ with a standard deviation of $0.055,0.02$ and 0.054 for hollow cone, solid cone and $3 \mathrm{D}$ action nozzles, respectively. The coefficient of determination $\left(\mathrm{R}^{2}\right)$ was 0.9839 for hollow cone nozzle, which indicates that 98.39 per cent of the variability of response could be explained by the model. The $\mathrm{R}^{2}$ value for solid cone and 3D action nozzles were 0.9956 and 0.9825 , respectively.

The model was obtained for representing the variation of discharge rate $\left(D_{r}\right)$ of hollow cone, Solid cone and 3Dnozzles were given below.

$\mathrm{D}_{\mathrm{r}}(\mathrm{HC})=-1.28+\left(5.66 \mathrm{P} \times 10^{-3}\right)+0.85264 \mathrm{H}$ $-\left(5.83 \mathrm{PH} \times 10^{-4}\right)-\left(2.59 \mathrm{P}^{2} \times 10^{-6}\right)-0.57 \mathrm{H}^{2}$ $\mathrm{D}_{\mathrm{r}}(\mathrm{SC})=0.68+\left(2.28 \mathrm{P} \times 10^{-3}\right)+0.33 \mathrm{H}+$ $\left(3.1 \mathrm{PH} \times 10^{-7}\right)-\left(5.61 \mathrm{P}^{2} \times 10^{-7}\right)-0.51 \mathrm{H}^{2}$ $\mathrm{D}_{\mathrm{r}}(3 \mathrm{D})=1.05+\left(2.68 \mathrm{P} \times 10^{-3}\right)+0.14 \mathrm{H}-$ $\left(8.29 \mathrm{PH} \times 10^{-5}\right)-\left(5.99 \mathrm{P}^{2} \times 10^{-7}\right)-0.22 \mathrm{H}^{2}$

The adequate precision was found to be 28.8 , 58.3 and 29.1 for hollow cone, Solid cone and 3Dnozzles, respectively. It measures the signal to noise ratio and it was found to be greater than 4 , therefore these models may be used to navigate the design space. The coefficient of variations for the observed discharge rate was $3.85,1.11$ and 2.10 for hollow cone, solid cone and 3D nozzles were obtained.

\section{Influence of operating pressure and nozzle height on droplet size}

The minimum droplet size of $114 \mu \mathrm{m}$ was obtained for hollow cone nozzle at operating pressure of $1000 \mathrm{kPa}$ and nozzle height of 0.4 $\mathrm{m}$. Whereas the maximum droplet size of 310 $\mu \mathrm{m}$ was obtained for $3 \mathrm{D}$ action nozzle at 400 $\mathrm{kPa}$ pressure and $0.40 \mathrm{~m}$ nozzle height. For the solid cone nozzle, the droplet size was varied from $138 \mu \mathrm{m}$ to $228 \mu \mathrm{m}$ and for hollow cone it was varied from $114 \mu \mathrm{m}$ to $191 \mu \mathrm{m}$ and for 3D nozzle, larger droplet size were observed in the range of $223 \mu \mathrm{m}$ to $310 \mu \mathrm{m}$. The quadratic polynomial model was fitted for each nozzle droplet size. It was observed that, the droplet size was decreased as the operating pressure and height of spray was increased (Fig. 1a, b and c).

In case of hollow cone nozzle, the rate decrease in droplet size was same throughout the range of operating pressure and nozzle height. But in case of solid cone nozzle, rate of reduction in droplet size was more initially later on once the pressure was crossed 850 kPaand then it was decreased. In 3D action nozzle, rate of change was more compared to solid cone nozzle. Overall, for same operating pressure, hollow cone nozzles were producing smaller droplets than solid cone and 3D action nozzle. This may be obtained because of more discharge rate from these nozzle and also in case of 3D action, it has three orifices, therefore overlapping of the droplets may have occurred. Operating pressure of the hydraulic nozzle determined the size of the droplets in the spray spectrum. High nozzle pressure disintegrates the liquid into smaller droplets. The same observation were recorded by Dahab and Eltahir (2010) and Jain et al., (2006). In regard to spray height, droplet size was decreased as the height of the nozzle was increased in all the three selected nozzles. But the effect of the nozzle height was very less as compared to the operating pressure. This was observed because, as the height of the spray 
was increased, the distance travelled by the droplets will be more, during this course of motion, droplets will disintegrate before reaching the surface. Azizpanah et al., (2015) observed the smaller diameters of droplet with increasing the height of the spray nozzle above the ground surface.

The mean droplet size obtained were 148.7, 184.9 and $274.4 \mu \mathrm{m}$ with a standard deviation of 3.98, 4.78 and 4.36 for hollow cone, solid cone and 3D nozzles, respectively. By statistical analysis, it was observed that both operating pressure $(\mathrm{P})$ and height of nozzle $(\mathrm{H})$ were significantly effecting the droplet size at 1 per cent level of significance. But the interaction does not have any significant effect on the droplet size of the spray. The $\mathrm{R}^{2}$ value was $0.9793,0.9769$ and 0.9604 were observed for hollow cone, solid cone and 3D nozzles, respectively.

The model equation obtained for predicting the variations in the droplet size $\left(D_{s}\right)$ for all the three nozzles were given below.

$\mathrm{D}_{\mathrm{s}}(\mathrm{HC})=265.12-0.18 \mathrm{P}-31.07 \mathrm{H}+0.02 \mathrm{PH}$ $+\left(3.69 \mathrm{P}^{2} \times 10^{-5}\right)-28.98 \mathrm{H}^{2}$

$\mathrm{D}_{\mathrm{s}}(\mathrm{SC})=230.76-\left(6.10 \mathrm{P} \times 10^{-3}\right)+75.23 \mathrm{H}-$ $0.03 \mathrm{PH}-\left(8.09 \mathrm{P}^{2} \times 10^{-5}\right)-118.88 \mathrm{H}^{2}$

$\mathrm{D}_{\mathrm{s}}(3 \mathrm{D})=313.01+0.06 \mathrm{P}-15.01 \mathrm{H}+0.02 \mathrm{PH}$ $-\left(1.44 \mathrm{P}^{2} \times 10^{-4}\right)-47.46 \mathrm{H}^{2}$

\section{Influence of operating pressure and nozzle height on spray uniformity}

The value of the spray uniformity should be near to unity for better results. The minimum spray uniformity of $1.46,1.79$ and 1.39 was obtained for hollow cone, solid cone and 3D action nozzles, respectively at $912 \mathrm{kPa}$ operating pressure and $0.26 \mathrm{~m}$ height of spray. At $400 \mathrm{kPa}$ operating pressure and $0.4 \mathrm{~m}$ nozzle height, the maximum spray uniformity of $2.10,2.30$ and 2.04 was obtained for hollow cone, solid cone and 3D action nozzles, respectively. The mean spray uniformity was $1.66,1.97$ and 1.59 with a standard deviation of $0.041,0.032$ and 0.048 for hollow cone, solid cone and 3D action nozzles, respectively. The effect of operating pressure and spray uniformity was shown in Fig. 3 ( $a, b$ and $c$ ) for hollow cone, solid cone and 3D action nozzles, respectively. In hollow cone nozzle spray uniformity was decreased as the operating pressure was increased from $400 \mathrm{kPa}$ to $700 \mathrm{kPa}$, but after that spray uniformity was almost constant. Similar trend was also observed for solid cone and 3D action nozzle. This was observed because, as the pressure was increased the droplet size decreases and after the $700 \mathrm{kPa}$, there was no significant change in the VMD of the droplet (Dahab and Eltahir, 2010; Tayel et al., 2009). As the nozzle height was increased, the spray uniformity was decreased but the effect was less compared to operating pressure. As the height of nozzle increases, the spray droplet disintegrates and smaller droplets were formed. If the VMD was reduced, this will decrease the spray uniformity value. Young (1990) found that the NMD fordroplets moving vertically down from the nozzle decreased by 10 per cent and the corresponding volume median diameter by 8 per cent. Similar trend was observed in Giteand Deogirikar (2010).

The operating pressure and height of nozzle were influencing the spray uniformity significantly at 1 per cent level of significance. The computed $\mathrm{R}^{2}$ value for the hollow cone, solid cone and 3D action nozzle were $0.9739,0.9753$ and 0.9487 , respectively. Adequate precision ratio of model was 23.566 which was greater than 4 , so it is in desirable condition. For the analysis, the final model equation for spray uniformity $\left(\mathrm{S}_{\mathrm{u}}\right)$ was developed for hollow cone nozzle, solid cone and $3 \mathrm{D}$ action nozzle was given below.

$\mathrm{S}_{\mathrm{u}}(\mathrm{HC})=3.66-\left(4.79 \mathrm{P} \times 10^{-3}\right)+0.07 \mathrm{H}-$ $\left(1.93 \mathrm{PH} \times 10^{-6}\right)+\left(2.77 \mathrm{P}^{2} \times 10^{-6}\right)-0.52 \mathrm{H}^{2}$ $\mathrm{S}_{\mathrm{u}}(\mathrm{SC})=3.49-\left(3.36 \mathrm{P} \times 10^{-3}\right)-0.26 \mathrm{H}+$ 
$\left(4.15 \mathrm{PH} \times 10^{-4}\right)+\left(1.69 \mathrm{P}^{2} \times 10^{-6}\right)-0.32 \mathrm{H}^{2}$ $\mathrm{S}_{\mathrm{u}}(3 \mathrm{D})=3.92-\left(5.26 \mathrm{P} \times 10^{3}\right)-0.75 \mathrm{H}+$ $\left(1.64 \mathrm{PH} \times 10^{-4}\right)+\left(2.96 \mathrm{P}^{2} \times 10^{-6}\right)+0.43 \mathrm{H}^{2}$

The CV of the observed spray uniformity values were 2.46, 1.65 and 3.02 per cent for hollow cone, solid cone and 3D action nozzles, respectively.

\section{Influence of operating pressure and nozzle height on droplet density}

The maximum droplet density of 156, 105 and 85 numbers per $\mathrm{cm}^{-2}$ were obtained at $1000 \mathrm{kPa}$ operating pressure and $0.4 \mathrm{~m}$ nozzle height for hollow cone, solid cone and 3D action nozzle, respectively. At $400 \mathrm{kPa}$ operating pressure and $0.40 \mathrm{~m}$ nozzle height, the minimum droplet density of 61, 43 and 31 numbers per $\mathrm{cm}^{2}$ were measured. When the nozzle height was increased from $0.2 \mathrm{~m}$ to 0.6 $\mathrm{m}$, the droplet density was increased from 91 to 107 No.s cm${ }^{-2}, 73$ to 89 No.s cm$~^{-2}$ and 57 to 68 No.s cm${ }^{-2}$ for hollow cone, solid cone and $3 \mathrm{D}$ action nozzle, respectively at $700 \mathrm{kPa}$ operating pressure. The mean values of droplet density were observed to be about 100.38, 78.15 and 61.07 for hollow cone, solid cone and 3D action nozzle, respectively.

The droplet density on the surface was increased as operating pressure was increased for all the three selected nozzles (Fig. 4 a, b and c). In case of hollow cone nozzle, the droplet density rate of change was slow initially and after $700 \mathrm{kPa}$ pressure, it was observed to be faster. This was observed may be due to decrease in the droplet size at higher pressure was more significant than lower operating pressure. But for both solid cone and $3 \mathrm{D}$ action nozzles, the rate of change was high initially, and reduced later on. This may be due to higher discharge at higher operating pressure, which may have reduced the droplet density after overlapping of the droplets. (Wandkar and Mathur, 2012;Gholap et al.,
2012; Narang et al., 2015).The effect of nozzle height was not as significant as operating pressure on droplet density, but it was observed that as the nozzle height was increased the droplet density was also increased. This was observed due to uniform distribution of spray spectrum as the nozzle height was increased. The same trend was also observed for all the three selected nozzles. These results concur with what was reported by Gupta et al., (2011), Dahab and Eltahir (2010), Ferguson et al., (2016) and Azizpanah et al., (2015).

The pressure was significantly influencing the droplet density at 1 per cent level of significance, independently. Whereas the nozzle height was influencing the droplet density at 5 per cent level of significance. The $\mathrm{R}^{2}$ value was found to be $0.9669,0.9761$ and 0.9897 for hollow cone, solid cone and 3D action nozzles, respectively. The model signal to noise ratio was more than 4 , therefore adequate signal and this model can be used to navigate in design space. The quadratic polynomial model was fitted to each of the selected nozzles for representing the variation of the droplet density $\left(D_{d}\right)$.

$\mathrm{D}_{\mathrm{d}}(\mathrm{HC})=37.04-\left(4.69 \mathrm{P} \times 10^{-3}\right)+39.38 \mathrm{H}+$ $0.02 \mathrm{PH}+\left(9.63 \mathrm{P}^{2} \times 10^{-5}\right)-21.15 \mathrm{H}^{2}$

$\mathrm{D}_{\mathrm{d}}(\mathrm{SC})=-35.25+0.20 \mathrm{P}+31.14 \mathrm{H}+(1.23$

$\left.\mathrm{PH} \times 10^{-4}\right)-\left(7.90 \mathrm{P}^{2} \times 10^{-5}\right)-2.98 \mathrm{H}^{2}$

$\mathrm{D}_{\mathrm{d}}(3 \mathrm{D})=-30.02+0.16 \mathrm{P}+18.32 \mathrm{H}+(3.49$

$\left.\mathrm{PH} \times 10^{-5}\right)-\left(5.76 \mathrm{P}^{2} \times 10^{-5}\right)+7.52 \mathrm{H}^{2}$

Influence of operating pressure and nozzle height on coefficient of variation in volumetric distribution

The CV of the volumetric distribution should be minimal for proper and efficient distribution of spray spectrum throughout its swath width. The $\mathrm{CV}$ of volumetric distribution across all three selected nozzles was varied from 6.10 to 18.60 per cent. It was 
observed that $\mathrm{CV}$ of volumetric distribution was obtained at $912 \mathrm{kPa}$ pressure and $0.56 \mathrm{~m}$ nozzle height was $8.30,8.10$ and 6.10 per cent for hollow cone, solid cone and $3 \mathrm{D}$ action nozzle, respectively. The 3D nozzle was having the lowest $\mathrm{CV}$ value followed by solid cone and hollow cone nozzles. The maximum CV of $18.60,15.30$ and 12.10 per cent was obtained at $400 \mathrm{kPa}$ operating pressure and $0.40 \mathrm{~m}$ nozzle height for hollow cone, solid cone and 3D action nozzle, respectively.

Among the selected nozzles, the 3D action nozzles had lowest $\mathrm{CV}$ value as there are three orifices were present and total discharge was distributed to all these three orifices evenly. The response of $\mathrm{CV}$ of volumetric distribution is plotted in Fig. 5 ( $a, b$ and c) for hollow cone, solid cone and 3D action nozzle, respectively. It was observed that, the $\mathrm{CV}$ value was decreased as the operating pressure was increased for all the three selected nozzles. Initially, the rate of decrease was high later, it was reduced once the operating pressure was above $700 \mathrm{kPa}$ and there was no reduction in the $\mathrm{CV}$ value was observed. This effect may be due to increase in the spray angle as the operating pressure was increased, so that the spray distribution was more uniform. In the later stages, there was no improvement in the spray angle; hence CV was recorded to be constant from that point of operating pressure(Sehsah and Kleisinger, 2009).It was also observed that, as the nozzle height was increased there was a decrease in the $\mathrm{CV}$ of volumetric distribution, as more uniform distribution of spray spectrum was observed.

The same trend was observed for all the three selected nozzles. This pattern was observed because, as the nozzle height was increased, the spray droplets were distributed evenly through the width even in case of high discharge. This was in concur with findings of Herbst and Wolf (2001).
The mean values of the CV were observed to be 12.07, 10.84 and 8.33 per cent with a standard deviation of $0.90,0.43$ and 0.35 for hollow cone, solid cone and 3D action nozzle, respectively. It was also observed that, operating pressure and nozzle height has a significant on $\mathrm{CV}$ values at 1 per cent level of significance. For hollow cone solid cone and $3 \mathrm{D}$ action nozzles, $\mathrm{R}^{2}$ was about 0.9406 , 0.9731 and 0.9721 , respectively.

The model equations were developed for $\mathrm{CV}$ of volumetric distribution $\left(\mathrm{C}_{\mathrm{v}}\right)$ in terms of operating pressure $(\mathrm{P})$ and nozzle height $(\mathrm{H})$.

$$
\begin{aligned}
& \mathrm{C}_{\mathrm{v}}(\mathrm{HC})=39.09-0.06 \mathrm{P}-4.73 \mathrm{H}+(7.46 \mathrm{PH} \\
& \left.\times 10^{-3}\right)+\left(2.98 \mathrm{P}^{2} \times 10^{-5}\right)-9.15 \mathrm{H}^{2} \\
& \mathrm{C}_{\mathrm{v}}(\mathrm{SC})=26.39-0.03 \mathrm{P}-6.18 \mathrm{H}+(5.82 \mathrm{PH} \\
& \left.\times 10^{-3}\right)+\left(1.09 \mathrm{P}^{2} \times 10^{-5}\right)-3.03 \mathrm{H}^{2} \\
& \mathrm{C}_{\mathrm{v}}(\mathrm{SC})=19.98-0.02 \times \mathrm{P}+1.17 \mathrm{H}+(4.99 \\
& \left.\mathrm{PH} \times 10^{-3}\right)+\left(9.25 \mathrm{P}^{2} \times 10^{-6}\right)-10.39 \mathrm{H}^{2}
\end{aligned}
$$

The coefficients of variation among the observed results of the experiment were about $7.52,3.98$ and 4.27 for hollow cone, solid cone and 3D action nozzle, respectively. This was within the accepted limit.

\section{Optimization of the operating parameters for the selected nozzles}

The operational parameters i.e.operating pressure and nozzle height were optimized for the each individual nozzle type based upon the required performance parameters.

The discharge rate should be within the limit, as it was one of the factors that affect the application rate of the sprayer. Present study was conducted for development of seven nozzle boom sprayer for cotton crop with 400 1 ha ${ }^{-1}$ application rate. Based on this, the nozzle has to deliver about $1.321 \mathrm{~min}^{-1}$ of spray discharge. 
Table.1 Variables selected for laboratory evaluation of nozzles

\begin{tabular}{|c|l|c|}
\hline Sl. no. & \multicolumn{1}{|c|}{ Parameters } & \multicolumn{1}{|c|}{ Independent } \\
\hline $\mathbf{1}$ & Type of nozzles & $\begin{array}{c}\text { Hollow cone nozzle, solid cone } \\
\text { nozzle, 3D action nozzle }\end{array}$ \\
\hline $\mathbf{2}$ & Operating pressure $(\mathrm{kPa})$ & $400,488,700,912$ and 1000 \\
\hline $\mathbf{3}$ & Nozzle Height $(\mathrm{m}) \quad$ Dependent & $0.20,0.26,0.40,0.54$ and 0.60 \\
\hline $\mathbf{1}$ & Discharge rate $\left(\mathrm{l} \mathrm{m}^{-1}\right)$ & \\
\hline $\mathbf{2}$ & Droplet size $(\mu \mathrm{m})$ \\
\hline $\mathbf{3}$ & Spray Uniformity & \\
\hline $\mathbf{4}$ & Droplet density (No's $\left.\mathrm{cm}^{-2}\right)$ & \\
\hline $\mathbf{5}$ & Spray volumetric distribution \\
\hline
\end{tabular}

Fig.1 Discharge rate as a function of nozzle height and operating pressure for (a) hollow cone nozzle (b) solid cone nozzle (c) 3D action nozzle

\section{Illustrations}

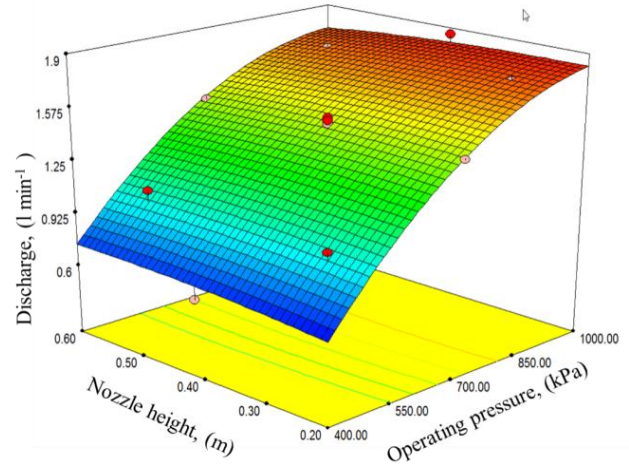

(a)

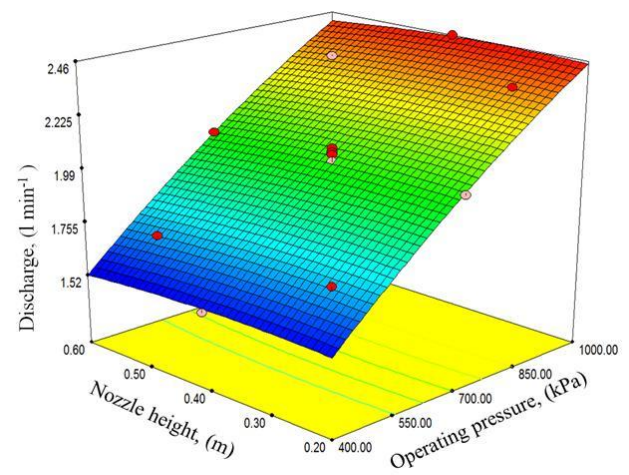

(b)

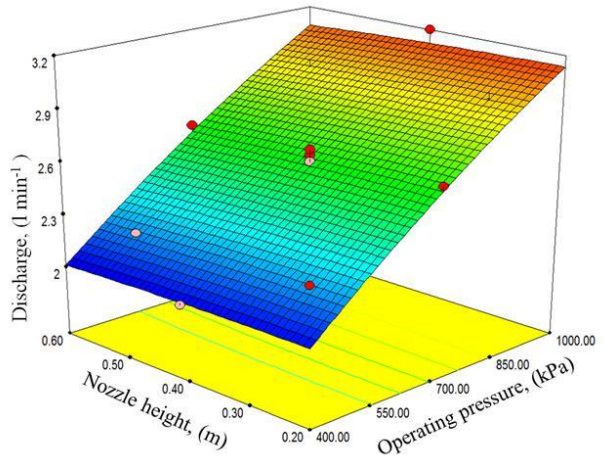

(c) 
Table.2 Optimum values of dependent variables for stability of high clearance small tractor for selected nozzles

\begin{tabular}{|c|c|c|c|c|c|c|c|c|}
\hline SI.No & $\begin{array}{c}\text { Operating } \\
\text { pressure }\end{array}$ & $\begin{array}{l}\text { Nozzle } \\
\text { height }\end{array}$ & $\begin{array}{c}\text { Discharge } \\
\text { rate } \\
\left(1 \mathrm{~min}^{-1}\right)\end{array}$ & $\begin{array}{l}\text { Droplet } \\
\text { size } \\
(\mu \mathrm{m})\end{array}$ & $\begin{array}{c}\text { Spray } \\
\text { Uniformity }\end{array}$ & $\begin{array}{c}\text { Droplet } \\
\text { density } \\
\left(\text { No's cm }{ }^{-2}\right)\end{array}$ & $\begin{array}{l}\text { C.V. in spray } \\
\text { volumetric } \\
\text { distribution }\end{array}$ & Desirability \\
\hline \multicolumn{9}{|c|}{ Hollow cone nozzle } \\
\hline 1 & 626 & 0.54 & 1.34 & 149 & 1.62 & 92 & 11.31 & 0.778 (Selected) \\
\hline 2 & 640 & 0.54 & 1.37 & 148 & 1.60 & 94 & 11.08 & 0.774 \\
\hline \multicolumn{9}{|c|}{ Solid cone nozzle } \\
\hline 1 & 668 & 0.54 & 1.98 & 184 & 1.91 & 81.43 & 10.20 & 0.573 \\
\hline 2 & 666 & 0.54 & 1.98 & 184 & 1.91 & 81.19 & 10.22 & 0.573 \\
\hline \multicolumn{9}{|c|}{ 3D action nozzle } \\
\hline 1 & 681 & 0.54 & 2.58 & 275 & 1.49 & 64.70 & 7.62 & 0.629 \\
\hline 2 & 675 & 0.54 & 2.56 & 275 & 1.50 & 64.23 & 7.67 & 0.628 \\
\hline
\end{tabular}

Fig.2 Droplet size as a function of nozzle height and operating pressure for (a) hollow cone nozzle (b) solid cone nozzle (c) 3D action nozzle

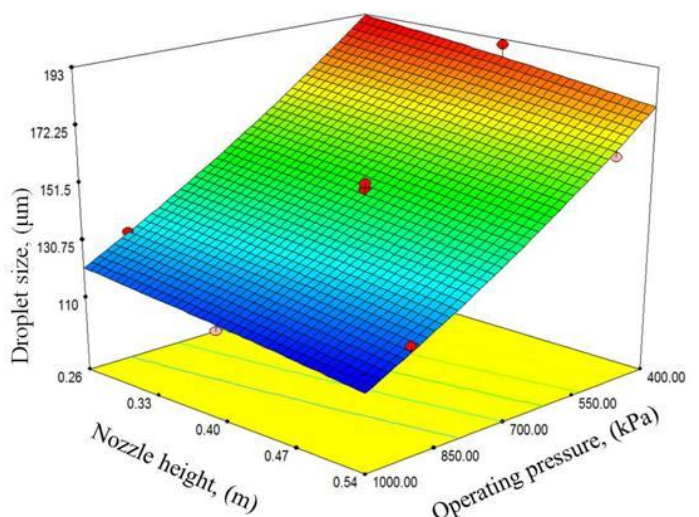

(a)

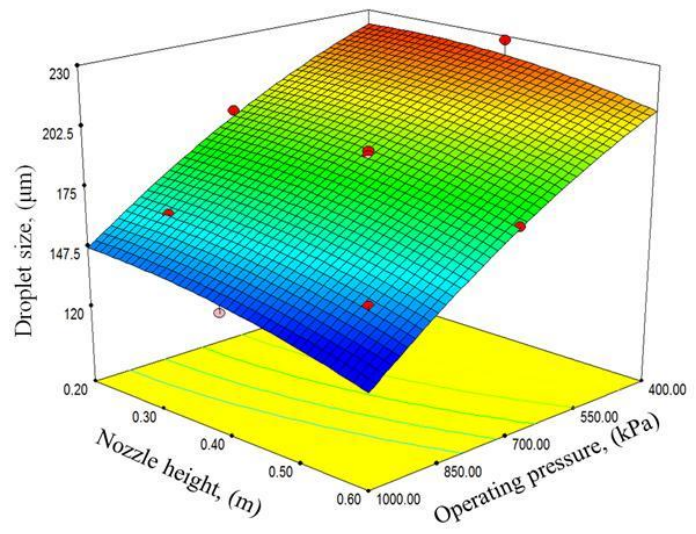

(b)

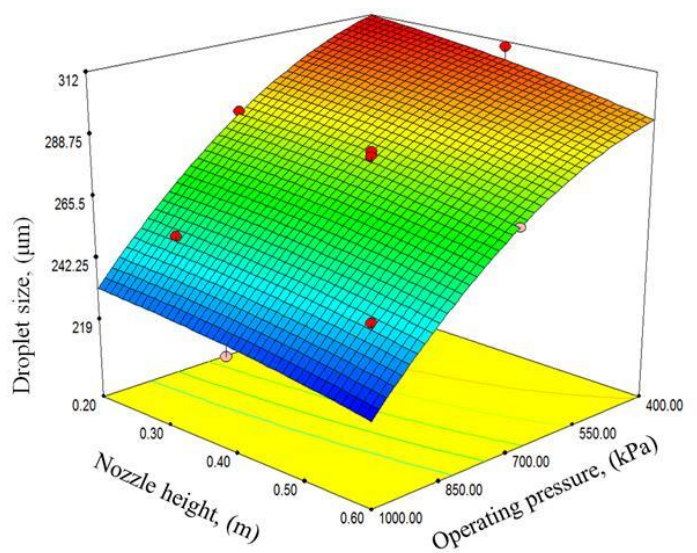

(c) 
Table.3 Predicted and actual values of responses under optimized treatment combination for hollow cone nozzles

\begin{tabular}{|c|c|c|c|c|}
\hline SI.No. & Responses & $\begin{array}{c}\text { Predicted } \\
\text { Values }\end{array}$ & $\begin{array}{c}\text { Actual } \\
\text { Values }\end{array}$ & $\begin{array}{c}\text { Per cent } \\
\text { Variation }\end{array}$ \\
\hline $\mathbf{1}$ & Discharge rate $\left(\mathrm{l} \mathrm{m}^{-1}\right)$ & 1.34 & 1.39 & 3.59 \\
\hline $\mathbf{2}$ & Droplet size $(\mu \mathrm{m})$ & 149 & 153 & 2.61 \\
\hline $\mathbf{3}$ & Spray Uniformity & 1.62 & 1.69 & 4.14 \\
\hline $\mathbf{4}$ & Droplet density(No's cm $\left.{ }^{-2}\right)$ & 92 & 89 & 3.37 \\
\hline $\mathbf{5}$ & C.V. in Vol. distribution $(\%)$ & 11.31 & 11.79 & 3.59 \\
\hline
\end{tabular}

Fig.3 Spray uniformity as a function of nozzle height and operating pressure for (a) hollow cone nozzle (b) solid cone nozzle (c) 3D action nozzle

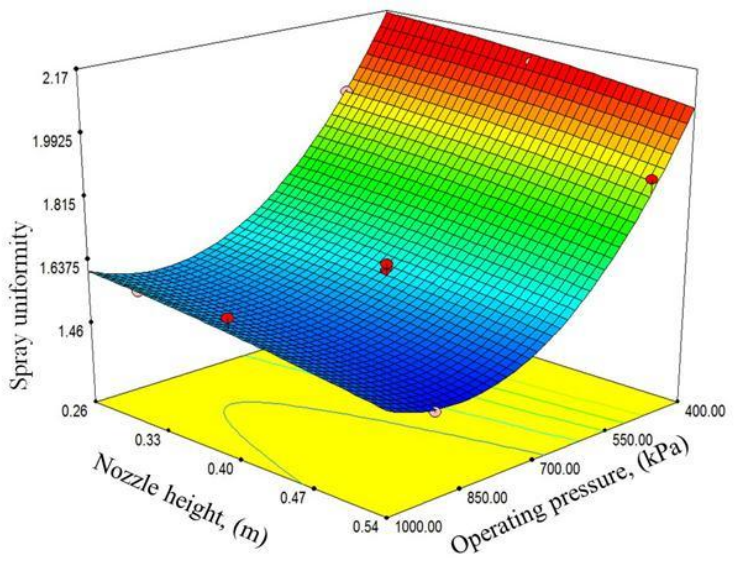

(a)

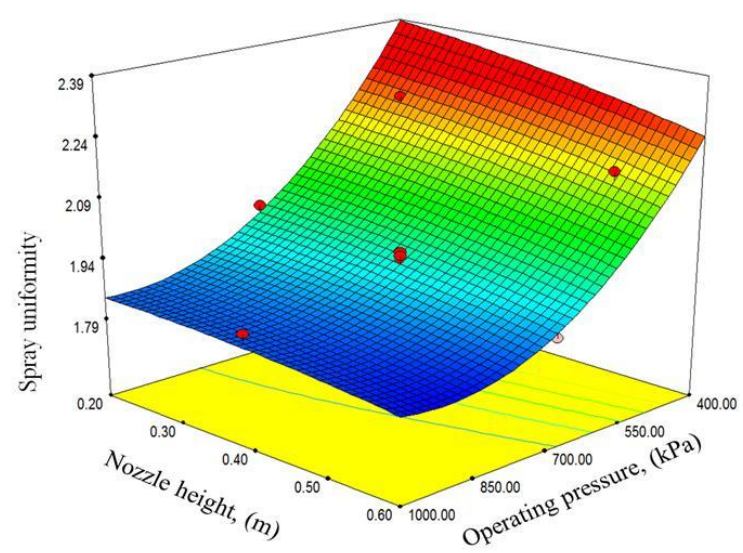

(b)

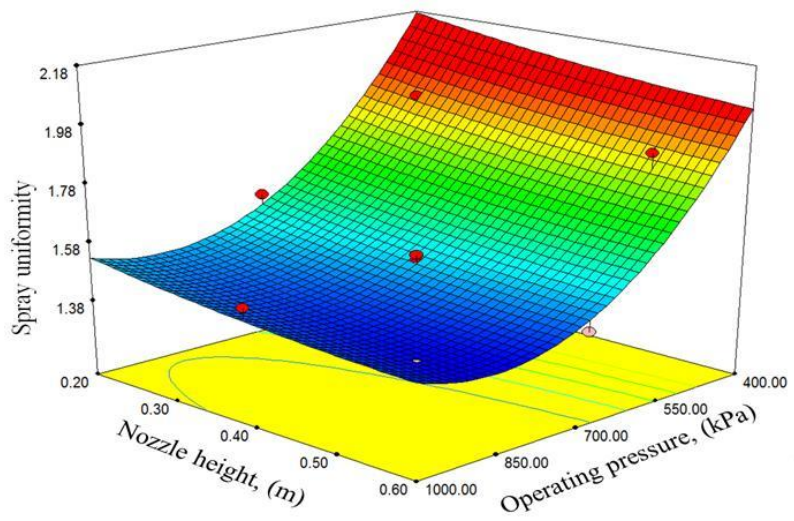

(c) 
Fig.4 Droplet density as a function of nozzle height and operating pressure for (a) hollow cone nozzle (b) solid cone nozzle (c) 3D action nozzle

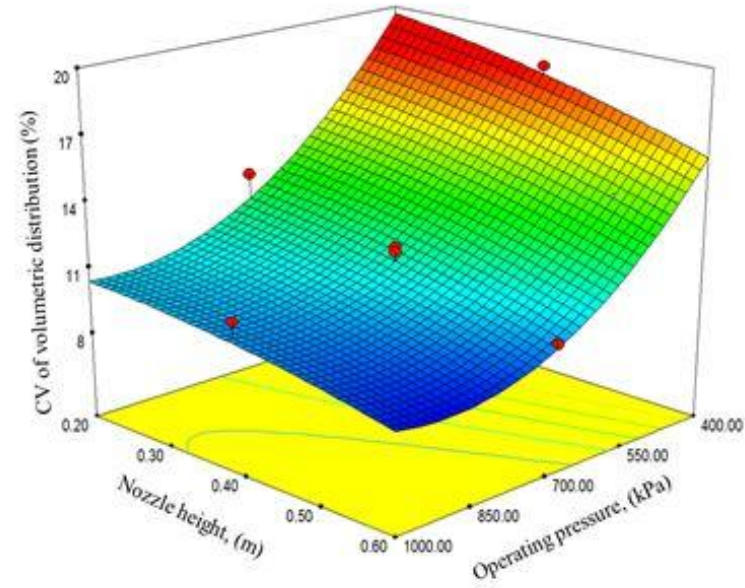

(a)

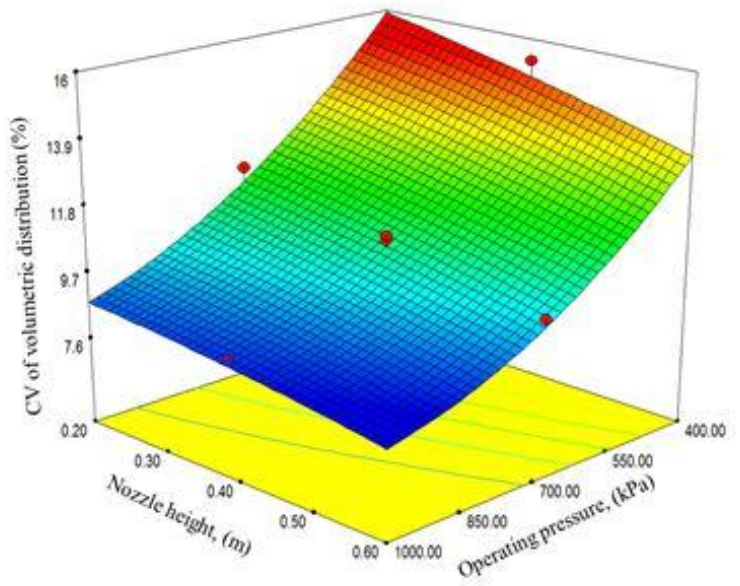

(b)

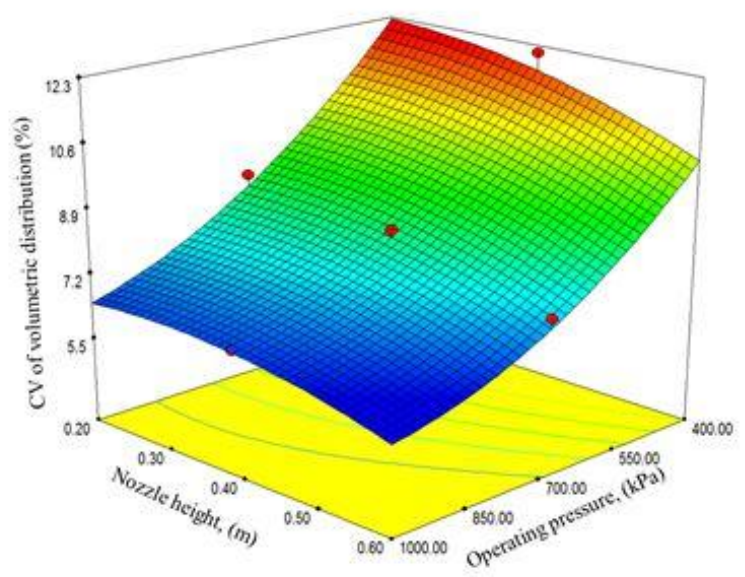

(c) 
Fig.5 Coefficient of variation of volumetric distribution as a function of nozzle height and operating pressure for (a) hollow cone nozzle (b) solid cone nozzle (c) 3D action nozzle

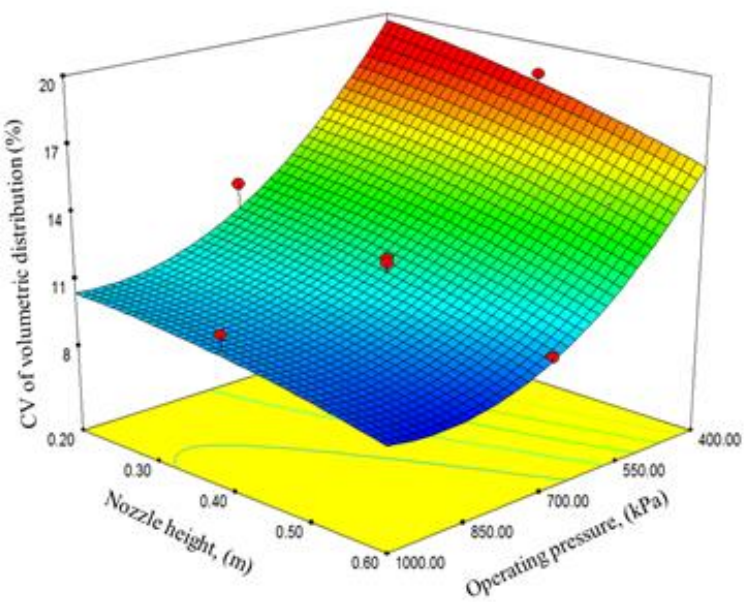

(a)

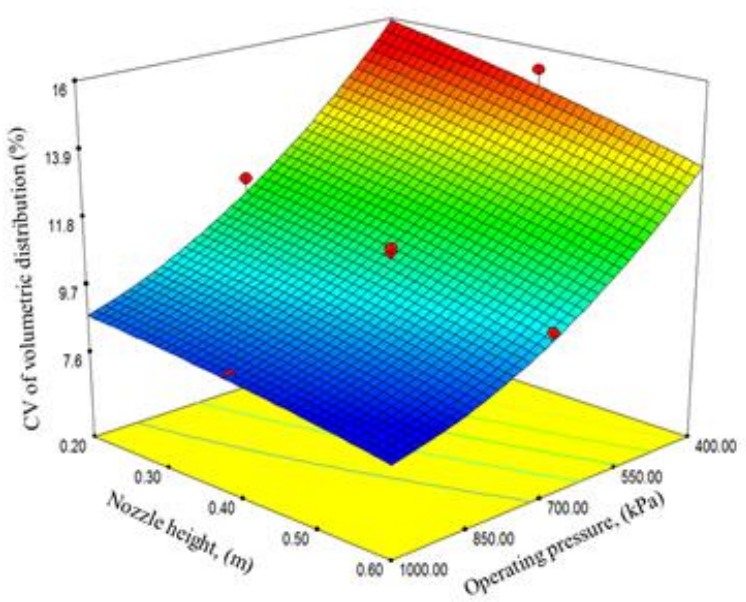

(b)

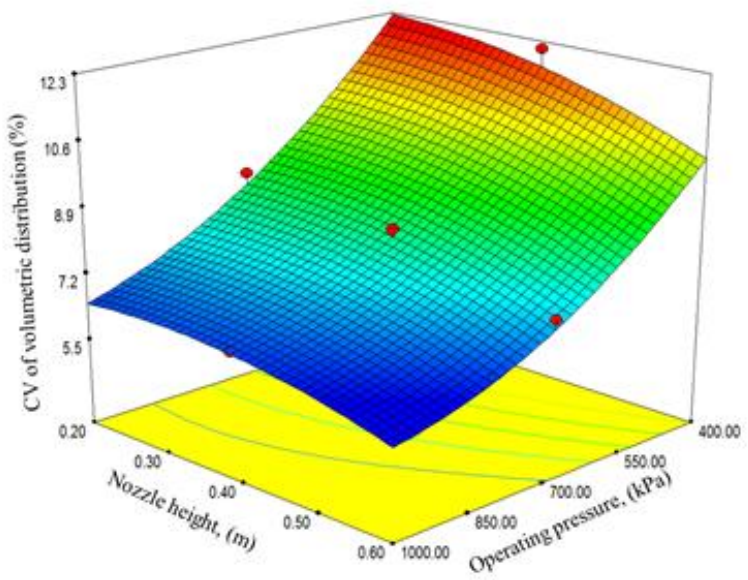

(c)

The droplet size of the spray spectrum is a deciding factor, as smaller the droplets better the spray, but the smaller droplet also causes drift and it should be within the limits. The value of spray uniformity and coefficient of volumetric distribution should be as low as possible. The droplet density should be more, so that more number of drops should be distributed on the canopy surface and more area coverage can be achieved.
Numerical optimization technique was adopted to obtain the optimum treatment combinations of experiment. The optimization was carried out using Design Expert software and the optimized values of operational parameters and their predicted performance parameters values were presented in Table 2.After analysing the predicted values of the performance values for all the three selected nozzles, the hollow cone nozzles were found 
suitable as its desirability level was also high compared to solid cone and 3D nozzles. Therefore, a hollow cone nozzle operated at $626 \mathrm{kPa}$ operating pressure and $0.56 \mathrm{~m}$ nozzle height with the predicted discharge rate 1.341 $\min ^{-1}$, droplet size of $149 \mu \mathrm{m}$, spray uniformity of 1.62, droplet density of 92 No.s $\mathrm{cm}^{-2}$ and coefficient of variation in volumetric distribution of 11.31 per cent with a desirability level of 0.778 . The predicted values were compared with the actual values after conducting the experiment at optimized operational parameters and results were presented in Table 3. The percentage of variations between actual and predicted values of discharge rate, droplet size, spray uniformity, droplet density and coefficient of variation in volumetric distribution were found to be 3.59, 2.61, 4.14, 3.37 and 3.59, respectively.

The present investigation concluded that hollow cone nozzle can be used for spraying operations in cotton crop operated at $626 \mathrm{kPa}$ operating pressure and $0.56 \mathrm{~m}$ nozzle height from canopy. Only operating pressure has influence on the discharge rate whereas nozzle height was non-significant. In case of droplet size, spray uniformity, droplet density and volumetric distribution were significantly influenced by both operating pressure and nozzle height for all three selected nozzles. The CV of volumetric distribution across all three selected nozzles was varied from 6.10 to 18.60 per cent. The 3D nozzle was having the lowest $\mathrm{CV}$ value followed by solid cone and hollow cone nozzles.

\section{References}

Azizpanah, A., Rajabipour, A., Alimardani, R., Kheiralipour, K., Ghamari, B. and Mohammadi, V., 2015, Design, construction and evaluation of a sprayer drift measurement system. Agric. Engg. Int., 17(3): 138-146.
Dahab, M. H. and Eltahir, N. B., 2010, Spray droplet number and volume distribution as affected by pressure and forward speed.Agric. Mech. Asia, Africa and Latin America, 41(4): 36-42.

Ferguson, J. C., Hewitt, A. J. and Donnell, C. O., 2016, Pressure, droplet size classification and nozzle arrangement on coverage and droplet density.Crop Prot., 89: 231-238.

Gholap, B., Mathur, R. and Dande, K. G., 2012, Laboratory performance evaluation of $12 \mathrm{~m}$ tractor mounted boom sprayer for cotton crop. Int. J. Agric. Engg., 5(1):31-36.

Gite, S. B. and Deogirikar, A. A., 2010, Design and testing of suitable boom for power tiller operated sprayer for bower type pattern of grape vineyard. Int. J. Agric. Engg.,3(2): 295-298.

Gupta, P., Sirohi, N. P. S. andKashyap, P. S., 2011, Effect of nozzle pressure, air speed, leaf area density and forward speed on spray deposition in simulated crop canopy. Annals of Hort., 4(1): 6371.

Herbst, A. and Wolf, P., 2001, Spray deposit distribution from agricultural boom sprayers in dynamic conditions.ASAE Meeting Paper 01-1054.

Iqbal, M., Mahmood and Younis, H. S., 2005, Development of a drop-pipe type university boom sprayer. J. Engg. Applied Sci., 24(2): 63-70.

Jain, S. K., Dhande, K .G., Aware, V. V. and Jaiswal, A. P., 2006, Effect of cone angle on droplet spectrum of hollow cone hydraulic nozzles. Agric. Mech. Asia, Africa and America, 37(1): 51-53.

Kathirvel, K., Job, T. V. and Manian, R., 2002, Development and evaluation of power tiller operated orchard sprayer. Agric. Mech. Asia, Africa and latin America, 33(3): 27-29.

Kepner, R. A., Bainer, R. and Barger, E. L., 2005, Principles of Farm 
Machinery.CBS Publishers \& Distributers (Pvt.) Ltd., New Delhi.

Manncsa, 2009, Pesticides in Agriculture, Agropedia.Pp. 265.

Matthews, G. A., 1992,Pesticide application methods, $2^{\text {nd }}$ ed., Longman, Scientific \& Technical, London: 405.

Minov, V., Cointault, F., Pieters, J. G. and Nuyttens, D., 2014, Spray nozzle characterization.Aspects of Applied Biology, 122: 353-363.

Narang, M., Mishra, A., Vijay Kumar., Thakur, S. S. and Singh, M., 2015, Comparative evaluation of spraying technology in cotton belt of Punjab (India).Sci. J. Ag. Engg., 1: 61-71.

Rahman, F., 2010, Design and development of a boom for a lever operated knapsack sprayer. M.Tech (Ag.Engg.)Thesis, Bangladesh agricultural university mymensingh.

Robert, B. and Hipkins, P., 2012, Accurate application and placement of chemicals on lawns.Biological Systems Engineering, Virginia Tech., BSE-
$39 \mathrm{NP}, 1-25$.

Safari, Mahmmod, Kafashan and Jalal, 2004, Development and evaluation of a mounted spinning disk sprayer in comparison with the conventional tractor mounted boom sprayers. Agric. Engg. Res. Inst., 1-20.

Sehsah, E. M. E. and Kleisinger, S., 2009, Study of some parameters affecting spray distribution uniformity pattern. Misr. J. Agri. Engg., 26(1): 69- 93.

Shashi, S. K., Surendra, S., Vaishali, S. and Nirmal, S., 2005, Performance of different nozzle for tractor mounted sprayers. J. Res., 43(1): 44-49.

Tayel, S., El-Nakib, A., Kamel, O. and Soliman, A. G., 2009, Development and evaluation of rice transplanting machine to use as spraying for cotton crop. $16^{\text {th }}$ Annual Conf. MisrSoci.Ag. Eng., p. 1447-1465.

Wandkar, S. L. and Mathur, S. M., 2012, Effect of air velocity and pump discharge on spray deposition. Int. J. Agric. Engg., 5(2): 133-137.

\section{How to cite this article:}

Sunil Shirwal, M. Veerangouda, Vijayakumar Palled, Sushilendra, Arunkumar Hosamani and Krishnamurthy, D. 2020. Studies on Operational Parameters of Different Spray Nozzles. Int.J.Curr.Microbiol.App.Sci. 9(01): 1267-1281. doi: https://doi.org/10.20546/ijcmas.2020.901.140 